Zeszyty Naukowe Szkoły Głównej Gospodarstwa Wiejskiego

Ekonomika i Organizacja Gospodarki Żywnościowej nr 114, 2016: 131-142

Dawid Olewnicki, Wioleta Sobczak, Lidia Gunerka

Samodzielna Pracownia Organizacji i Ekonomiki Ogrodnictwa

Szkoła Główna Gospodarstwa Wiejskiego w Warszawie

\title{
Zainteresowanie warszawskich konsumentów owocami mało znanymi i egzotycznymi
}

\section{Wstęp}

Zachowania konsumpcyjne gospodarstw domowych podlegaja ciagłym przemianom zarówno w czasie, jak i w różnych warunkach otoczenia. Ogólna dostępność dóbr żywnościowych na rynku, konkurencyjne ceny, atrakcyjność ofert podażowych, a także zmieniające się upodobania i preferencje konsumentów spowodowały istotne zmiany $\mathrm{w}$ zachowaniach konsumpcyjnych nabywców. Sprzyjało to przede wszystkim substytucji pomiędzy produktami i w obrębie ich grup, a także poszukiwaniu produktów wygodnych w użyciu [Adamczyk 2002]. Promocja zdrowego stylu życia oraz prawidłowego odżywiania się jest w Polsce zjawiskiem stosunkowo nowym. Regularne spożywanie owoców jest jednym z podstawowych elementów racjonalnego żywienia, a także odgrywa istotną rolę w profilaktyce oraz zwalczaniu wielu chorób. Ze względu na wyjątkową różnorodność gatunkową owoców stanowią one bogate źródło składników pokarmowych. Ich duża wartość biologiczna wynika głównie z zawartości witamin, zwłaszcza witaminy C, składników bioaktywnych w tym karotenoidów, a także składników mineralnych [Kazimierczak i Świetlikowska 2006].

W ostatnich latach, przy ogólnym spadku spożycia owoców, obserwowano wzrost spożycia przez konsumentów owoców pochodzących z krajów południowych. Przyczynił się do tego gwałtowny rozwój handlu międzynarodowego szczególnie importu. Niewątpliwie pozytywnym aspektem tego zjawiska jest wzbogacenie różnorodności dostępnych dla konsumentów gatunków. Jednocześnie nie należy zapominać, że rozwój importu wpływa negatywnie na sytuację krajowych producentów, dla których jest on dużym zagrożeniem, głównie ze względu na stosunkowo konkurencyjne ceny, wysoką jakość produktów oraz 
ich odmienny charakter. Jak podkreśla Olewnicki (2010), już sam egzotyczny charakter owoców południowych nadaje im znacznej przewagi konkurencyjnej. Jednym z rozwiązań dla krajowych producentów jest dywersyfikacja produkcji i wprowadzanie na rynek owoców mniej znanych, których produkcja możliwa jest w naszych warunkach klimatycznych.

Celem niniejszego opracowania była ocena nabywania i znajomości owoców mało popularnych i egzotycznych wśród warszawskich konsumentów.

\section{Metodyka}

Podstawą analiz zamieszczonych w niniejszym opracowaniu były badania ankietowe, przeprowadzone w 2014 roku, wśród 185 respondentów spotkanych na terenie Warszawy w okolicach sklepów, centrów handlowych oraz pikników rodzinnych. Zastosowano w tym przypadku metodę doboru nielosowego, przypadkowego. Formularz ankietowy zawierał pytania zamknięte dotyczące znajomości mało popularnych gatunków owoców zarówno uprawianych w Polsce, jak i importowanych, a także innych gatunków egzotycznych. W ankiecie celowo pominięto powszechnie znane i dostępne gatunki importowane, takie jak np. banany, pomarańcze, mandarynki, winogrona, kiwi. Listę 30 gatunków stworzono na podstawie pilotażowych obserwacji przeprowadzonych głównie w sklepach wielkopowierzchniowych oraz ofert rynków hurtowych. Ponadto pytania dotyczyły nabywania wskazanych gatunków, postaci spożywanych owoców oraz miejsca ich nabycia. Jako tło do analiz z badań ankietowych przedstawiono zmiany $\mathrm{w}$ wielkość podaży owoców importowanych (w klasyfikacjach GUS zwanych owocami południowymi) dostępnych na rynku krajowym. Podaż obliczono, odejmując od wielkości importu wielkość reeksportu tej grupy towarowej. Przedstawiono także wielkość spożycia owoców południowych w porównaniu do jabłek jako gatunku mającego największe znaczenie w konsumpcji owoców w Polsce. Okres badawczy obejmował lata 2000-2014.

Analizy wykonano metodami matematyczno-statystycznymi. Wykorzystano narzędzia, techniki i metody analiz zależności oraz statystyki opisowej. Badano dynamikę zmian (przyjmując za 100\% pierwszy rok badanego okresu) oraz średnie roczne tempo zmian.

Zgodnie z teorią ekonomii, wg której wraz ze wzrostem zamożności rośnie popyt i chęć nabywania dóbr wyższego rzędu, zbadano, czy istnieje zależność pomiędzy dochodami respondentów a chęcią zakupu przez nich wybranych gatunków owoców. W związku z tym, iż nabywanie lub chęć nabycia owoców jest cechą jakościową, w analizach korelacji wykorzystano metody statystyki 
chi-kwadrat. W celu zbadania powyższych zależności określono współczynnik kontyngencji $\varphi$ Yule'a, przy poziomie istotności wynoszącym $\alpha=0,05$.

Wyniki badań zaprezentowano za pomocą wskaźników procentowych $\mathrm{w}$ formie graficznej (wykresy oraz tabele). W pracy wykorzystano również dane i materiały wtórne, pochodzące z publikacji naukowych oraz pracy dyplomowej, których zakres badań obejmował podobną tematykę.

\section{Zmiany w konsumpcji i handlu owocami w Polsce}

Okres ostatnich 25 lat to czas wielu zmian na polskim rynku, zarówno o charakterze ekonomiczno-społecznym, jak i te dotyczące świadomości konsumenckiej. W miarę rozwoju gospodarczego i wzrostu zamożności społeczeństwa zmienia się poziom oraz struktura spożycia żywności [Klepacki 2008]. W związku z tymi przeobrażeniami zmienia się nie tylko struktura spożycia określonych produktów żywnościowych w kraju, ale również struktura środków finansowych przeznaczanych na zakup poszczególnych artykułów spożywczych oraz dóbr wyższego rzędu [Kwasek 2000]. Akcesja Polski do struktur UE wywołała wyraźne ożywienie gospodarcze w kraju, a także wzrost zamożności, który przełożył się na wzrost konsumpcji towarów i usług, a jak wynika z danych NBP (2014) - szczególnie widoczne jest to w ostatnich latach.

Wśród produktów żywnościowych możemy wyróżnić wiele artykułów, których spożycie nie jest determinowane jedynie potrzebami pierwszego rzędu. Do takich artykułów należy wiele gatunków owoców, choć bardzo często traktowane są już jako dobra podstawowe. Pomimo wzrostu zamożności polskiego społeczeństwa, spożycie owoców ogółem w Polsce od lat sukcesywnie spada, a zjawisko to szczególnie widoczne jest od momentu wstąpienia Polski do UE [Olewnicki 2009 i 2010]. Należy podkreślić, że w 2014 r. spożycie świeżych owoców ogółem w gospodarstwach domowych na jedną osobę wynosiło $41,3 \mathrm{~kg}$, w 2004 r. - 46,4, a w 2000 r. - ponad $48 \mathrm{~kg}$; zatem biorąc pod uwagę rok 2014, spożycie owoców było w stosunku do 2000 roku aż o $15 \%$ niższe. Średnie roczne tempo spadku spożycia owoców w tym okresie wyniosło $1,1 \%$.

Jabłka są gatunkiem, który ma największe znaczenie w krajowej konsumpcji owoców, choć jak podkreślają Olewnicki [2011] i Jąder [2014] - od lat ich spożycie maleje. Przeprowadzone analizy wskazuja, iż od 2000 do 2014 roku spożycie jabłek spadło, w przeliczeniu na jedną osobę w gospodarstwie domowym, z 22,9 do $14,0 \mathrm{~kg}$, a więc prawie o $40 \%$. Średnie roczne tempo spadku wyniosło $\mathrm{w}$ tym czasie $3,5 \%$. Zatem, przy obserwowanej spadkowej tendencji spożycia jabłek, przetwórstwo i eksport prawdopodobnie będą nadal najważniejszymi sposobami zagospodarowania ich produkcji, chociaż jak przypuszcza Makosz 
(2015), w najbliższych latach konsumpcja może wzrosnąć do 20 kg/mieszkańca, pod warunkiem, że nadal będzie skuteczna promocja jabłek w całym kraju (wynikająca m.in. z embarga rosyjskiego), przede wszystkim przez oferowanie jabłek wysokiej jakości i odmian preferowanych przez konsumentów.

Zjawisko spadku spożycia jabłek obserwowano wcześniej w USA, Niemczech $\mathrm{i}$ innych krajach rozwiniętych gospodarczo. W Stanach Zjednoczonych w okresie 100-letnim wraz ze wzrostem zamożności społeczeństwa popyt na jabłka spadał z 30,1 kg w latach 1910-1911 do 8,2 kg (na osobę) w latach 2005-2006 [Brzozowski 2009]. Oznacza to, że jabłka stały się w tym kraju dobrem podstawowym. W Polsce prawdopodobnie stały się już dobrem podstawowym, choć jeszcze na początku minionej dekady, wg Adamczyk (2002), nadal uważane były za dobra wyższego rzędu. Spadającej konsumpcji jabłek towarzyszą zmiany w strukturze spożycia owoców, ich różnorodności, a także sukcesywny wzrost spożycia owoców południowych [Olewnicki 2010]. Zmiany te szczególnie widoczne od akcesji Polski do struktur UE. W 2000 roku spożycie owoców południowych na jedną osobę w gospodarstwie domowym wynosiło średnio 10,8 kg, a w 2014 roku - już $13,5 \mathrm{~kg}$, zatem w stosunku do 2000 roku wzrosło o $24,5 \%$, przy średniorocznym tempie wzrostu spożycia wynoszącym 1,6\% (rysunek 1).

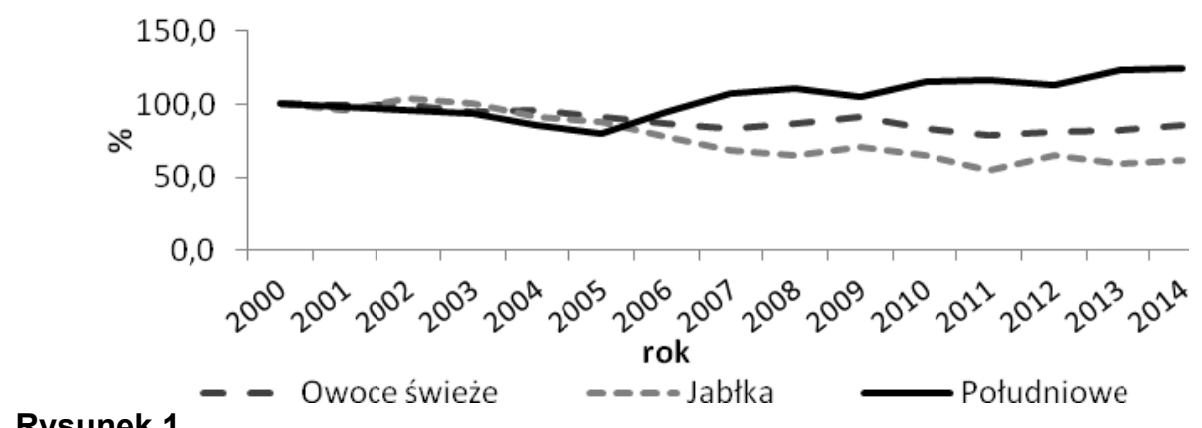

\section{Rysunek 1}

Dynamika spożycia wybranych grup owoców na jedną osobę/rok w gospodarstwach domowych w latach 2000-2014

Źródło: Opracowanie własne na podstawie IERiGŻ-PIB - Analizy Rynkowe - Rynek owoców.

Wzrastające spożycie owoców południowych miało istotny wpływ na rozwój handlu zagranicznego tym asortymentem w kraju. Przeprowadzone analizy wskazują, że w latach 2000-2014 sukcesywnie wzrastała wielkość podaży owoców importowanych na rynku krajowym. W 2014 roku była ona o $20 \%$ wyższa niż na początku badanego 14-lecia (rysunek 2). Średnie roczne tempo wzrostu podaży wyniosło w tym okresie $1,3 \%$.

Należy podkreślić, iż w klasyfikacjach GUS można wyodrębnić głównie gatunki, których wolumen importu jest największy. Do takich gatunków należą m.in. banany, pomarańcze, cytryny, mandarynki i winogrona. Wiele gatunków 


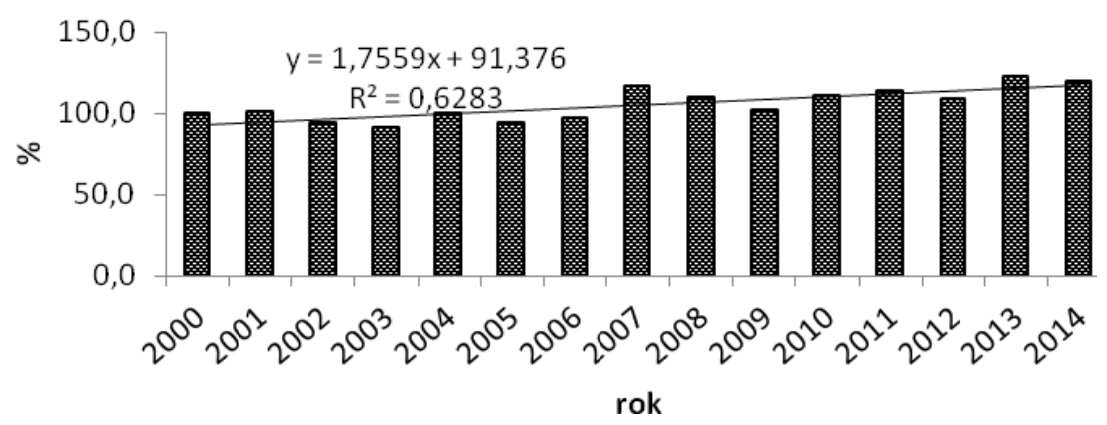

\section{Rysunek 2}

Dynamika podaży owoców importowanych na rynku krajowym w latach 2000-2014 (w \%) Źródło: Opracowanie własne na podstawie IERiGŻ-PIB - Analizy Rynkowe - Rynek owoców.

stosunkowo nowych na naszym rynku, zarówno możliwych w krajowej produkcji, jak i importowanych klasyfikowanych jest w statystykach dotyczących spożycia i handlu jako ,pozostałe”. Z tego też względu niezwykle trudno określić zmiany ich znaczenia na rynku, chociaż rosnąca ich dostępność jest coraz bardziej widoczna, szczególnie w sklepach wielkopowierzchniowych. Warto zaznaczyć, że różnorodność gatunkowa owoców na świecie jest bardzo duża, chociaż na polski rynek dociera niewielka ich liczba, to z pewnością w przyszłości będzie ona się zwiększać. Najlepszym tego przykładem jest owoc pomelo, który w Chinach znany jest od tysięcy lat, natomiast na polskim rynku pojawia się dopiero od kilku lat, a konsumenci coraz bardziej cenią ten owoc (Fresh-Market 2013). Jak podaje Cock (2005), w Amerykach Północnej i Południowej występuje ponad 1000 gatunków jadalnych owoców, powszechnie dostępnych na rynku jest zaś ok. 100. W południowej Azji można znaleźć ok. 500 gatunków, na subkontynencie indyjskim - 300, w Afryce zaś - ponad 1200 gatunków jadalnych owoców. Chociaż w połowie minionej dekady $89 \%$ światowego rynku owoców tropikalnych stanowiły cytrusy, banany, mango i ananasy, to bez watpienia rynek ten rozwija się dzięki zainteresowaniu nowymi gatunkami.

\section{Znajomość owoców mało popularnych i egzotycznych wśród konsumentów}

Rozwój Internetu, a także mediów, które w coraz większym stopniu promują zdrowy styl życia poprzez emisję programów edukacyjnych i kulinarnych z pewnością w dużym stopniu przyczynia się do wzrostu świadomości konsumentów odnośnie różnorodności gatunkowej m.in. owoców występujących na krajowym rynku. Przeprowadzone badania wskazały, że gatunki owoców zaproponowane respondentom $w$ arkuszu ankietowym można podzielić na trzy grupy, tj. dobrze 
znane, średnio oraz mało znane. Wśród owoców dobrze znanych przez respondentów można wskazać takie gatunki, jak liczi, owoce pigwy oraz figi, których znajomość deklarowało odpowiednio: 76, 72 i 71\% ankietowanych (rysunek 3). Do grupy dobrze znanych owoców można zaliczyć również awokado, kasztany jadalne, papaję, granaty oraz marakuję. Znajomość tych owoców wskazała ponad połowa ankietowanych. Do gatunków średnio znanych, które wskazało od 20 do 38\% respondentów można zaliczyć m.in. makadamię, karambolę, świdośliwę, gujawę, a także pitaję. Warto w tym miejscu wskazać jagodę kamczacka, aktinidię, gruszę azjatycka, a więc gatunki, które w ostatnich latach wchodzą do towarowej produkcji sadowniczej. Ich znajomość deklaruje odpowiednio: 30, 35 oraz 37\% respondentów. Pozostałe zaproponowane gatunki owoców, m.in takie jak durian czy rambutan, okazały się być mało znane. W każdym przypadku wskazało je poniżej $1 / 5$ badanych.

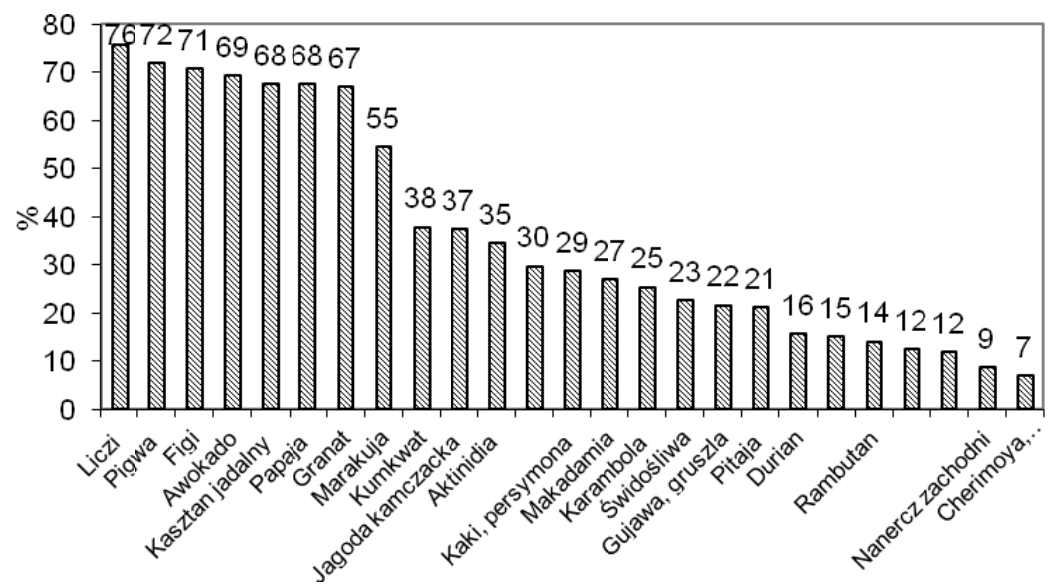

\section{Rysunek 3}

Znajomość mało popularnych i egzotycznych owoców wśród respondentów (w \% wskazań ankietowanych)

Źródło: Badania własne.

Fakt znajomości przez potencjalnych nabywców wymienionych gatunków nie był jednoznaczny z jego kupowaniem, choć jak wskazują badania, znaczna większość respondentów nabywa wiele wskazanych gatunków. Najwięcej respondentów, bo ponad połowa, kupuje figi, awokado i granaty (odpowiednio: 57, 60 i 64\%). Wśród gatunków często wskazywanych jako kupowane przez respondentów znalazły się również: liczi (44\%), pigwa (43\%), papaja (35\%) i marakuja (24\%). Najmniej, bo tylko do $2 \%$ respondentów nabywa duriany, flaszowce i rambutany.

Biorąc pod uwagę przyczyny nienabywania powyższych owoców, respondenci najczęściej wymieniali brak znajomości miejsca ich sprzedaży. Taki fakt wskazało aż 


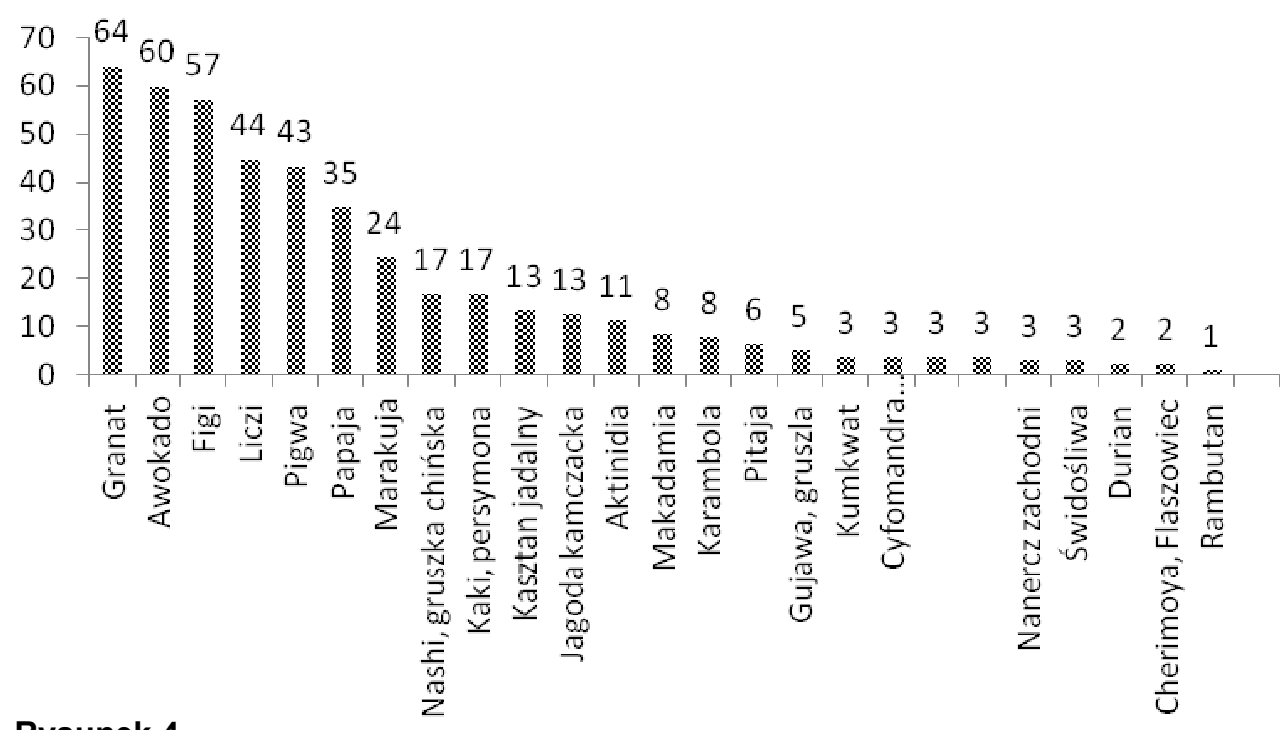

\section{Rysunek 4}

Nabywanie przez respondentów owoców mało popularnych i egzotycznych (w \% wskazań ankietowanych)

Źródło: Badania własne.

$35 \%$ ankietowanych nienabywających powyższych gatunków. Pomimo tego, że potencjalni konsumenci znają mało popularne owoce, to bardzo często nie mają wiedzy o ich zastosowaniu, co podkreśliło 34\% respondentów. Aż 26\% konsumentów nie nabywa analizowanych gatunków ze względu na zbyt wysoką cenę (rysunek 5).

Owoce nabywane przez respondentów spożywane są głównie w postaci świeżej bez przetworzenia, na co wskazało $90 \%$ ankietowanych. Drugim sposobem

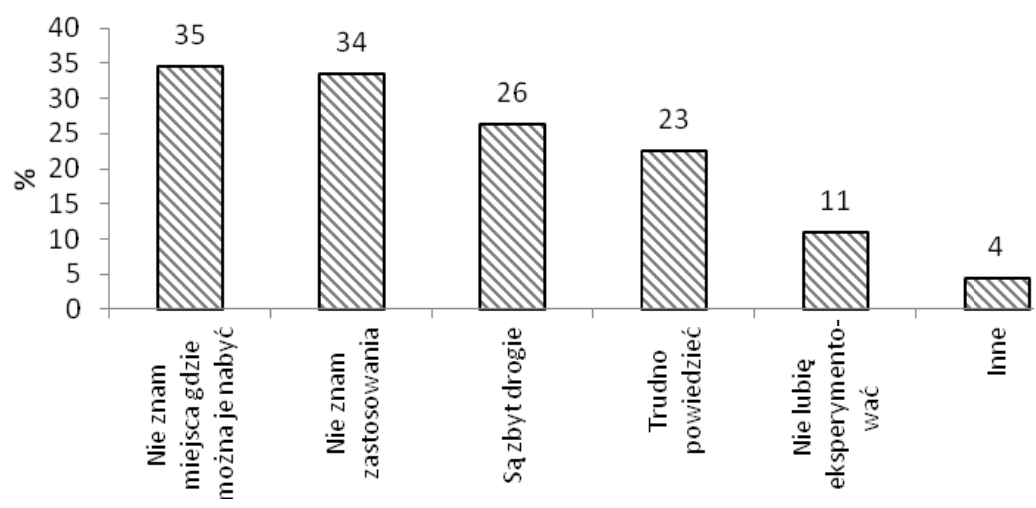

\section{Rysunek 5}

Powody nienabywanie przez respondentów wybranych gatunków owoców mało popularnych i egzotycznych ( $w$ \% wskazań ankietowanych)

Źródło: Badania własne. 
wykorzystania owoców południowych, wskazanym przez 28\% respondentów, było sporządzanie surówek lub sałatek owocowych. Wśród popularnych zastosowań nabywanych owoców należy wymienić wykorzystanie ich jako dodatek do innych potraw, na co wskazało $21 \%$ respondentów. Podobna liczba konsumentów (18\%), która zakupiła mało popularne lub egzotyczne owoce wykorzystywała je do przetworów (rysunek 6). Jak wynika z przeprowadzonych analiz, respondenci najczęściej nabywają analizowane owoce w hipermarketach. Tak wskazało prawie 3/4 ankietowanych. Dla prawie połowy respondentów również

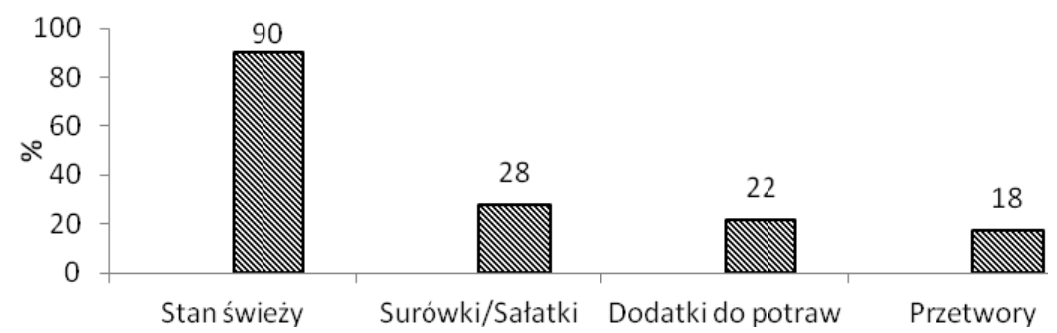

\section{Rysunek 6}

Sposób spożycia owoców mało popularnych i egzotycznych przez respondentów (w \% wskazań ankietowanych)

Źródło: Badania własne.

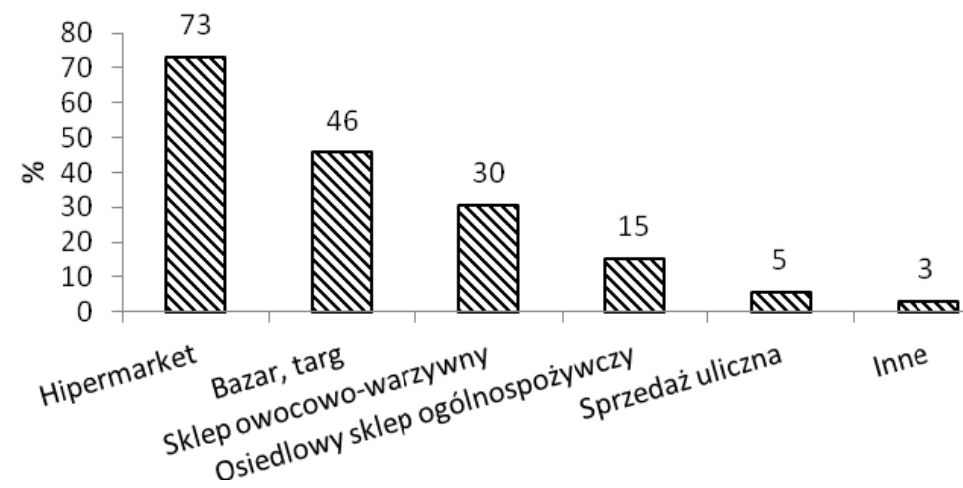

\section{Rysunek 7}

Miejsca zakupu owoców mało popularnych i egzotycznych wśród respondentów (w \% wskazań ankietowanych)

Źródło: Badania własne.

targ lub bazar jest ważnym miejscem zakupu tej grupy artykułów (rysunek 7).

Jak podkreślają Olewnicki (2009), Karczewska (2010), Gutkowska i Morawska (2013), na ilość nabywanych owoców istotny wpływ ma wysokość dochodów konsumentów, które stają się wyznacznikiem proporcji wydatków na żywność w tym na owoce. W związku z tym zbadano wpływ dochodów respon- 
dentów na nabywanie wybranych gatunków przedstawionych w ankiecie. W tym celu wybrano 3 gatunki, które najczęściej wskazywali respondenci, tj. granaty, awokado i figi. Przeprowadzone analizy wykazały, że większość respondentów (ponad połowa), których dochody w gospodarstwach domowych w przeliczeniu na 1 osobę nie przekraczały 500 zł, w ogóle nie nabywa tych gatunków (tabela 1). $\mathrm{Z}$ kolei należy podkreślić, że w grupach dochodowych, w których dochód wyniósł powyżej 500 zł na osobę, zaobserwowano niewielki wzrost odsetka respondentów deklarujących kupowanie tych gatunków. Jednak na podstawie przeprowadzonej analizy korelacji, w której określono współczynniki kontyngencji $\varphi$ Yule'a, nie wykazano zależności między badanymi zmiennymi. Wartość tych współczynników dla 3 analizowanych gatunków nie przekroczyła 0,23 , co zgodnie z zasadami statystyki, świadczy o słabej współzależności pomiędzy analizowanymi cechami.

Tabela 1

Wysokość dochodu a zakup wybranych owoców

\begin{tabular}{|c|c|c|c|c|c|}
\hline \multicolumn{2}{|c|}{ Dochód (zł) } & $<500$ & $501-1000$ & $1001-1500$ & $>1500$ \\
\hline \multicolumn{6}{|c|}{ Suma wskazań respondentów [\%] } \\
\hline \multirow{2}{*}{ Granat } & kupuje & 28 & 48 & 55 & 53 \\
\hline & nie kupuje & 72 & 52 & 45 & 47 \\
\hline \multirow[t]{2}{*}{ Awokado } & kupuje & 39 & 41 & 38 & 57 \\
\hline & nie kupuje & 61 & 59 & 62 & 43 \\
\hline \multirow[t]{2}{*}{ Figi } & kupuje & 17 & 41 & 43 & 54 \\
\hline & nie kupuje & 83 & 59 & 57 & 46 \\
\hline
\end{tabular}

Źródło: Badania własne.

\section{Podsumowanie i wnioski}

Przeprowadzone badania wskazują, że w latach 2000-2014 nastąpił stopniowy wzrost podaży owoców południowych na rynku krajowym. Z pewnością był on odpowiedzią na rosnące zainteresowanie konsumentów tymi owocami, przejawiające się wzrostem ich spożycia przy jednoczesnym spadku spożycia krajowych gatunków, szczególnie jabłek. Mimo że nadal mają one największe znaczenie w spożyciu świeżych owoców, to wielkość ich wyraźnie się zmniejsza. Należy podkreślić, że w latach 2000-2014 roczne spożycie jabłek w gospodarstwach domowych na jedną osobę spadało z 22,9 do $14,0 \mathrm{~kg}$, a więc prawie o $40 \%$. Może być to spowodowane zwiększającą się różnorodnością gatunkową owoców na rynku, wywołaną rozwojem handlu 


\section{0}

zagranicznego, a także zwiększającą się świadomością i ciekawością konsumentów dotyczącą nowych gatunków owoców znajdujących się na rynku krajowym. Prawdopodobnie duże znaczenie w tym przypadku może mieć rozwój i dostępność informacji w Internecie, w programach edukacyjnych oraz kulinarnych. Na podstawie przeprowadzonych analiz, spośród gatunków owoców przedstawionych $w$ kwestionariuszu ankietowym, wyróżniono 3 grupy, tj. owoce dobrze znane (m.in. liczi, owoc pigwy, figi), średnio znane (m.in. aktinidia, jagoda kamczacka) oraz owoce mało znane (m.in. durian, mangostan właściwy). Badania wykazały również, że najczęściej nabywanymi przez ankietowanych owocami z zaproponowanych były granaty, awokado i figi. Zakupione owoce spożywane są przez $90 \%$ respondentów, głównie w stanie świeżym. Warto podkreślić, iż najważniejszym miejscem zakupu tych gatunków jest hipermarket, na który wskazało prawie $3 / 4$ respondentów.

Najczęstszą przyczyną nienabywania przez konsumentów wskazanych owoców był brak znajomości miejsc ich sprzedaży lub brak wiedzy na temat ich zastosowania. Niskie dochody respondentów (do 500 zł na osobę na miesiąc) również miały wpływ na nienabywanie wybranych gatunków owoców. Wśród pozostałych grup dochodowych zaobserwowano nieznaczny odsetka respondentów deklarujących kupowanie tych gatunków, jednak nie zaobserwowano tu istotnej statystycznie zależności.

\section{Literatura}

ADAMCZYK G., 2002: Wybrane aspekty zachowań konsumpcyjnych $i$ wzorców spożycia żywności w polskich gospodarstwach domowych w latach dziewięćdziesiatych. Roczniki Akademii Rolniczej w Poznaniu CCCXLIII 1:31-41.

COCK J., 2005: The CIAT Tropical Fruits Program. Tropical Horticulture - Texas A\&M University.

Fresh Market 2013: http://www.freshmarket.pl/owoce_i_warzywa/owoce/owoce_cytrusowe/wysoka_podaz_pomelo_na_rynku,p1356112569

GUTKOWSKA K., MURAWSKA A A., 2013: Poziom życia ludności a wielkość i struktura spożycia żywności $w$ aspekcie regionalnym. Handel Wewnętrzny 2013; 4 (345): 47-60.

IERiGŻ-PIB - Analizy Rynkowe - Rynek owoców z lat 2001-2015.

JĄDER K., 2014: Zmiany w konsumpcji owoców i ich przetworów w Polsce w latach 1998-2012. Roczniki Naukowe Stowarzyszenia Ekonomistów Rolnictwa i Agrobiznesu tom 101, zeszyt 3:98-106.

KARCZEWSKA M., 2010: Determinanty zachowań konsumenckich na rynku. Sympozja i konferencje KKMU, 5, s. 475-484. 
KAZIMIERCZAK R., ŚWIETLIKOWSKA K., 2006: The importance of origin from the organic production as a factor Influencing purchase and consumption of fruits and vegetables in the urban and rural households. Jurnal of Research in Agricultural Engineering 51 (2): 74-81.

KLEPACKI B., 2008: Przestanki zmiany roli rolnictwa $w$ gospodarce narodowej. Materiały promocyjne SGGW, Warszawa.

KWASEK M., 2000: Wspótzależność między spożyciem żywności a poziomem dochodów $w$ świetle wspótczynników dochodowej elastyczności spożycia (popytu). Mat. Konf. „Konsument żywności i jego zachowania rynkowe”, Warszawa: 155-159.

MAKOSZ E., 2015: Przyszłość polskich jabłek. Biuletyn Informacyjn Agencji Rynku Rolnego, 3:10-15.

NPB 2014: Sytuacja gospodarcza w krajach Europy Środkowej i Wschodniej. Wyd. Instytut Ekonomiczny NBP, Warszawa.

OLEWNICKI D., 2009: Wplyw dochodu na spożycie owoców $i$ wydatki na owoce $w$ Polsce w latach 1998-2008. Monografia - Handel owocami w Polsce i Austrii teraz i w przyszłości, Lublin, 77-83.

OLEWNICKI D., 2010. Spożycie krajowych gatunków owoców wobec konkurencji ze strony importu owoców południowych. Roczniki Naukowe Stowarzyszenia Ekonomistów Rolnictwa i Agrobiznesu tom 12, zeszyt 4: 235-239.

OLEWNICKI D., 2011: Przemiany w gospodarce ogrodniczej w Polsce w latach 1965-2008 oraz perspektywy jej rozwoju. Praca doktorska, SGGW w Warszawie.

MAKOSZ E., 2011. Wielkość zbiorów i opłacalność produkcji jabłek, gruszek, wiśni i czereśni. Mat. XXXI Międzynarodowe Seminarium Sadownicze „Prognoza wielkości zbiorów, potrzeby i opłacalność produkcji owoców w kraju w najbliższych latach”, Limanowa, 37-49.

\section{Abstrakt}

Celem niniejszego opracowania była ocena nabywania i znajomości owoców mało popularnych oraz egzotycznych wśród warszawskich konsumentów. Dane do analiz pozyskane zostały za pomocą badań ankietowych przeprowadzonych wśród 185 respondentów w 2014 roku na terenie Warszawy.

Przeprowadzone badania wskazały, że pomimo tego, iż znaczna część przedstawionych w kwestionariuszu ankietowym gatunków owoców jest dla polskich konsumentów stosunkowo dobrze znana, to tylko nieliczne są przez nich nabywane. Badania wskazują, że do głównych przyczyn tego stanu należy mała dostępność miejsc ich sprzedaży oraz ich wysokie ceny.

Słowa kluczowe: jabłka, owoce południowe, owoce egzotyczne, spożycie 


\title{
Polish consumers' interest in exotic and little-known fruits
}

\begin{abstract}
The aim of this study was to evaluate acquisition and awareness among consumers with regard to little popular and exotic fruits. Data for the analysis were obtained through a survey conducted among 185 respondents in 2014 in Warsaw.

The study showed that despite the fact that a significant part provided in the questionnaire species of fruit for Polish consumers well known, but a few are purchased by them. Research indicates that the main reasons for this include low availability of many species and their high prices.
\end{abstract}

Key wods: apples, south fruits, exotic fruits, consumption 